\title{
Ghrelin-induced cSrc activation through constitutive nitric oxide synthase-dependent S-nitrosylation in modulation of salivary gland acinar cell inflammatory responses to Porphyromonas gingivalis
}

\author{
Bronislaw L. Slomiany, Amalia Slomiany \\ Research Center, University of Medicine and Dentistry of New Jersey, Newark, USA. \\ E-mail: slomiabr@umdnj.edu
}

Received 9 March 2011; revised 20 April 2011; accepted 28 April 2011.

\begin{abstract}
A peptide hormone, ghrelin, recognized for its role in the regulation of nitric oxide production has emerged as an important modulator of oral mucosal inflammatory responses to periodontopathic bacterium, $P$. gingivalis. As cSrc kinase plays a major role in controlling the activity of nitric oxide synthase (NOS) system, in this study we investigated the influence of $P$. gingivalis LPS on the processes of Src activation in rat sublingual gland acinar cells. The LPS-induced enhancement in the activity of inducible (i) iNOS and the impairment in constitutive (c) cNOS were reflected in the suppression in cSrc activity and the extent of its phosphorylation at $\mathrm{Tyr}^{416}$. Further, we show that the countering effect of ghrelin on the LPSinduced changes in cSrc activity and the extent of its phosphorylation was accompanied by a marked reduction in iNOS and the increase in cNOS activation through phosphorylation at $\operatorname{Ser}^{1179}$. Moreover, the effect of ghrelin on cSrc activation was associated with the kinase S-nitrosylation that was susceptible to the blockage by cNOS inhibition. Our findings suggest that $P$. gingivalis-induced up-regulation in iNOS leads to disturbances in cNOS phosphorylation that exerts the detrimental effect on the processes of cSrc activation through cNOS mediated S-nitrosylation. We also show that the effect of ghrelin on $P$. gingivalis-induced inflammatory changes are manifested in the enhancement in cSrc activation through S-nitro- sylation and the increase in its phosphorylation at $\mathrm{Tyr}^{416}$.
\end{abstract}

Keywords: Ghrelin; P. Gingivalis; Salivary Acinar Cells; cNOS; cSrc Activation; S-Nitrosylation

\section{INTRODUCTION}

Ghrelin, a 28-amino acid peptide hormone, initially isolated from the stomach $[1,2]$, and more recently identified in oral mucosa, saliva and the acinar cells of salivary glands [3], is recognized as an important modulator of oral mucosal inflammatory responses to periodontopathic bacterium, $P$. gingivalis through the regulation of nitric oxide synthase (NOS) isozyme system [4-6]. The signaling mechanism that underlies the regulation of $\mathrm{NO}$ by ghrelin involves the stimulation of growth-hormone secretagogue receptor type 1a (GHSR1a), a seven-transmembrane G-protein coupled receptor, that leads to activation of heterotrimeric $G$ protein-dependent network of protein kinases, including that of cellular Src (cSrc), a member of the non-receptor protein tyrosine kinase Src family [7-10]. All currently known eleven members of the Src family kinases share similar structural organization, consisting of N-terminal myristoylation motif that facilitates membrane attachment, followed by the protein binding SH3 and SH2 homology domains, a protein tyrosine kinase domain, and a C-terminal regulatory tail $[8,10]$.

The $60 \mathrm{kDa}$ phosphoprotein $\left(\mathrm{pp} 60^{c-s r c}\right)$ Src is encoded by a physiological $c$-src gene, which is cellular homologue of the highly transforming $v$-src gene of Rouse sarcoma virus [8,11,12]. The activity of cSrc is tightly regulated by reversible phosphorylation on $\mathrm{Tyr}^{527}$ and $\mathrm{Tyr}^{416}$ amino acid residues, which either inactivates or activates the kinase. The inhibitory phosphorylation at $\mathrm{Tyr}^{527}$ of C-terminal tail locks the kinase in an inactive dormant conformation through the interaction with its SH2 domain [9]. The dormant form of the enzyme is destabilized by dephosphorylation or displacement of the inhibitory $\mathrm{Tyr}^{527}$ from the SH2 binding pocket, thus ex- 
posing the activation loop to autophosphorylation at $\mathrm{Tyr}^{416}$ which stabilizes the enzyme in its active state [9, 11]. Furthermore, there are indications that in addition to phosphorylation/dephosphorylation-based circuitry of Src activation, the activity of cSrc may be also regulated through S-nitrosylation at the kinase cysteine residues located within the C-terminal region of its catalytic domain $[11,13,14]$.

Indeed, protein modification through targeted S-nitrosylation at the critical cysteine residues, with the involvement of both constitutive and inducible forms of NOS system, is gaining recognition as an important posttranslational event of significance to a variety of biological processes affected by NO [4-6,13,14]. Moreover, the NO-induced Src protein S-nitrosylation has been shown to promote the kinase activation through autophosphorylation at $\mathrm{Tyr}^{416}$ that appears to be independent of the phosphorylation status of C-terminal $\mathrm{Tyr}^{527}$ autoinhibitory site [14-16].

As oral mucosal inflammatory responses to periodontopathic bacterium, $P$. gingivalis, are characterized by the disturbances in NO production, and since cSrc kinase plays a central role in transduction of signals that regulate the activity of NOS isozyme system [4,5,13,14], in this study we investigated the impact of $P$. gingivalis key virulence factor, LPS, on the cSrc kinase activity in sublingual salivary gland acinar cells. Moreover, considering the demonstrated role of ghrelin in the regulation of NOS system $[4,5,17]$, we examined the influence of this peptide hormone on processes of cSrc activation through S-nitrosylation.

\section{MATERIALS AND METHODS}

\subsection{Sublingual Salivary Gland Cell Incubation}

The acinar cells of sublingual salivary gland, collected from freshly dissected rat salivary glands, were suspended in five volumes of ice-cold Dulbecco's modified (Gibco) Eagle's minimal essential medium (DMEM), supplemented with fungizone $(50 \mu \mathrm{g} / \mathrm{ml})$, penicillin (50 $\mathrm{U} / \mathrm{ml})$, streptomycin $(50 \mu \mathrm{g} / \mathrm{ml})$, and $10 \%$ fetal calf serum, and gently dispersed by trituration with a syringe, and settled by centrifugation [18]. After rinsing, the cells were resuspended in the medium to a concentration of 2 $\times 10^{7} \mathrm{cell} / \mathrm{ml}$, transferred in $1 \mathrm{ml}$ aliquots to DMEM in culture dishes and incubated under 95\% $\mathrm{O}_{2}-5 \% \mathrm{CO}_{2}$ atmosphere at $37^{\circ} \mathrm{C}$ for $16 \mathrm{~h}$ in the presence of $P$. gingivalis LPS [5]. In the experiments evaluating the effect of ghrelin (rat, Sigma), cNOS inhibitor, L-NAME, iNOS inhibitor, $1400 \mathrm{~W}$, Src inhibitor, PP2, (Calbiochem), and ascorbate (Sigma), the cells were first preincubated for 30 min with the indicated dose of the agent or vehicle before the addition of the LPS. The viability of cell preparations before and during the experimentation, as- sessed by Trypan blue dye exclusion assay [18], was greater than $98 \%$.

\subsection{Porphyromonas Gingivalis Lipopolysaccharide}

P. gingivalis used for LPS preparation was cultured from clinical isolates obtained from ATCC No. 33277 [19]. The bacterium was homogenized with liquid phenolchloroform-petroleum ether, centrifuged, and the LPS contained in the supernatant was precipitated with water, washed with $80 \%$ phenol solution and dried with ether. The dry residue was dissolved in a small volume of water at $45^{\circ} \mathrm{C}$, centrifuged at $100,000 \times \mathrm{g}$ for $4 \mathrm{~h}$, and the resulting LPS sediment subjected to lyophilization. Analyses indicated that such obtained LPS preparation was essentially free of nucleic acids as determined by absorption at $260 \mathrm{~nm}$, and its protein content, measured by BCA assay kit, was less than $0.2 \%$.

\subsection{NO Production, and cNOS and iNOS Activity Assay}

NO production in the acinar cells of sublingual salivary gland was determined by measuring the stable NO metabolite, nitrite, accumulation in the culture medium using Griess reaction [20]. A $100 \mu \mathrm{l}$ of spent culture medium was incubated for $10 \mathrm{~min}$ with $0.1 \mathrm{ml}$ of Griess reagent (Sigma) and the absorbance was measured at $570 \mathrm{~nm}$. The activity of cNOS and iNOS enzymes was measured by monitoring the conversion of $\mathrm{L}-\left[{ }^{3} \mathrm{H}\right]$ arginine to L- $\left[{ }^{3} \mathrm{H}\right]$ citrulline using NOS-detect kit (Stratagene). The acinar cells from the control and experimental treatments were homogenized in a sample buffer containing either $10 \mathrm{mM}$ EDTA (for $\mathrm{Ca}^{2+}$-independent iNOS) or 6 $\mathrm{mM} \mathrm{CaCl}_{2}$ (for $\mathrm{Ca}^{2+}$-dependent cNOS), and centrifuged $[5,18]$. The aliquots of the resulting supernatant were incubated for $30 \mathrm{~min}$ at $25^{\circ} \mathrm{C}$ in the presence of 50 $\mu \mathrm{Ci} / \mathrm{ml}$ of L- $\left[{ }^{3} \mathrm{H}\right]$ arginine, $10 \mathrm{mM}$ NAPDH, $5 \mu \mathrm{M}$ tetrahydrobiopterin, and $50 \mathrm{mM}$ Tis-HCl buffer, $\mathrm{pH}$ 7.4, in a final volume of $250 \mu \mathrm{l}$. Following addition of stop buffer and Dowex-50 W $\left(\mathrm{Na}^{+}\right)$resin, the mixtures were transferred to spin cups, centrifuged and the formed L$\left[{ }^{3} \mathrm{H}\right]$ citrulline contained in the flow through was quantified by scintillation counting.

\subsection{Src Kinase Activity Assay}

Tyrosine kinase activity of cSrc in sublingual salivary gland acinar cells was measured by using $\operatorname{polyE}_{4} \mathrm{Y}$ (Sigma) and $\left[\gamma-{ }^{32} \mathrm{P}\right]$ ATP (Amersham) as the substrates [21]. The cells were lysed in lysis buffer (20 mM Tris$\mathrm{HCl}, \mathrm{pH}$ 7.4, $150 \mathrm{mM} \mathrm{NaCl}, 1 \%$ Triton X-100, 0.5\% sodium deoxycholate, $2 \mathrm{mM}$ EDTA, $1 \mathrm{mM}$ sodium orthovanadate, $1 \mathrm{mM}$ PAF, and $1 \mathrm{mM} \mathrm{NaF}$ ), containing protease inhibitor cocktail (Sigma), at $4^{\circ} \mathrm{C}$ for $30 \mathrm{~min}$, 
centrifuged at $12,000 \times g$ for $10 \mathrm{~min}$, and the supernatants were subjected to protein determination using BCA protein assay kit (Pierce). The supernatant samples containing equal total protein content were then immunoprecipitated with anti-Src antibody (Sigma) for $2 \mathrm{~h}$ at $4^{\circ} \mathrm{C}$. Protein $\mathrm{A} / \mathrm{G}$ agarose beads were added for an additional $1 \mathrm{~h}$, and the immune complex was recovered by centrifugation and thoroughly washed with lysis buffer. The agarose beads were then suspended for 30 min at room temperature in the kinase assay buffer (10 $\mathrm{mM}$ Tris-HCl, $\mathrm{pH}$ 7.4, $150 \mathrm{mM} \mathrm{NaCl}, 5 \mathrm{mM} \mathrm{MgCl}_{2}, 5$ $\mathrm{mM} \mathrm{MnCl} 2,2$ mM EDTA, and 2 mM dithithreitol), centrifuged, and the supernatants used for the Src activity assay. For this, the samples containing $25 \mu \mathrm{g}$ of the cell homogenate protein in $50 \mu$ l of Src kinase assay buffer were incubated with $1 \mathrm{mg} / \mathrm{ml}$ of polyE $4 \mathrm{Y}$ and $100 \mathrm{mM}$ ATP containing $10 \mu \mathrm{Ci}$ of $\left[\gamma-{ }^{32} \mathrm{P}\right] \mathrm{ATP}$, at $30^{\circ} \mathrm{C}$ for 20 min. The reaction was terminated by adding $25 \mu$ of $40 \%$ trichloroacetic, the samples were spotted onto phosphorcellulose paper, and following thorough washing with $1 \%$ phosphoric acid and then acetone [22], the radioactivity incorporated into polyE $\mathrm{E}_{4} \mathrm{Y}$ was determined by liquid scintillation counting.

\subsection{Src Kinase Phosphorylation Assay}

Measurements of the phosphorylation status of cSrc at $\mathrm{Tyr}^{416}$ in sublingual salivary gland acinar cells were conducted using Phospho-Src (Tyr416) ELISA kits (Cell Signaling). The acinar cells were lysed on ice for $30 \mathrm{~min}$ in lysis buffer (20 mM Tris-HCl, pH 7.5, $150 \mathrm{mM} \mathrm{NaCl,}$ 1 mM EDTA, 1 mM EGTA, 1\% Triton X-100, 2.5 mM sodium pyrophosphate, $1 \mathrm{mM}$ sodium orthovanadate, 1 $\mathrm{mM} \beta$-glycerophosphate, $1 \mathrm{mM}$ PMSF, $1 \mu \mathrm{g} / \mathrm{ml}$ leupeptin), and centrifuged at $12,000 \times g$ for $10 \mathrm{~min}$. The supernatants diluted (1:1) in standard diluent buffer were pipetted in $100 \mu \mathrm{l}$ aliquots into wells containing immobilized capture antibody specific for Src $\left(\mathrm{pTyr}^{416}\right)$, and following washing the complex was reacted with Src detection antibody. After washing, the retained complex was labeled with horseradish peroxidase and probed with TMB reagent for spectrophotometric quantification at $450 \mathrm{~nm}$.

\subsection{Src Protein S-Nitrosylation Assay}

Assessment of cSrc kinase S-nitrosylation in the acinar cells of sublingual salivary gland was conducted using a biotin switch procedure for protein S-nitrosylation [23, 24]. The cells were treated with iNOS inhibitor, $1400 \mathrm{~W}$ (30 $\mu \mathrm{M})$ or cNOS inhibitor, L-NAME $(200 \mu \mathrm{M})$, or ghrelin $(0.6 \mu \mathrm{g} / \mathrm{ml})$, and incubated for $16 \mathrm{~h}$ in the presence of $100 \mathrm{ng} / \mathrm{ml}$ of $P$. gingivalis LPS. Following centrifugation at $500 \times \mathrm{g}$ for $5 \mathrm{~min}$, the recovered cells were lysed in $0.2 \mathrm{ml}$ of HEN lysis buffer (250 mM HEPES, 1
mM EDTA, $0.1 \mathrm{mM}$ neocuprin, $\mathrm{pH}$ 7.7), and the unnitrosylated thiol groups were blocked with S-methyl methane-thiosulfonate reagent at $50^{\circ} \mathrm{C}$ for $20 \mathrm{~min}$ [24]. The proteins were precipitated with acetone, resuspended in $0.2 \mathrm{ml}$ of HEN buffer containing 1\% SDS, and subjected to targeted nitrothiol group reduction with sodium ascorbate $(100 \mathrm{mM})$. The free thiols were then labeled with biotin and the biotinylated proteins were recovered on streptavidin beads. The formed streptavidin bead-protein complex was washed with neutralization buffer, and the bound proteins were dissociated from streptavidin beads with $50 \mu \mathrm{l}$ of elution buffer $(20 \mathrm{mM}$ HEPES, 100 mM NaCl, 1 mM EDTA, pH 7.7) containing 1\% 2-mercap-toethanol [24]. The obtained proteins were then analyzed by Western blotting.

\subsection{Immunoblotting Analysis}

The acinar cells of sublingual salivary gland from the control and experimental treatments were collected by centrifugation and resuspended for $30 \mathrm{~min}$ in ice-cold lysis buffer (20 mM Tris-HCl, $\mathrm{pH}$ 7.4, $150 \mathrm{mM} \mathrm{NaCl}$, $10 \%$ glycerol 1\% Triton X-100, 2 mM EDTA, $1 \mathrm{mM}$ sodium orthovanadate, $4 \mathrm{mM}$ sodium pyrophosphate, $1 \mathrm{mM}$ PMSF, and $1 \mathrm{mM} \mathrm{NaF}$ ), containing $1 \mu \mathrm{g} / \mathrm{ml} \mathrm{leu-}$ peptin and $1 \mu \mathrm{g} / \mathrm{ml}$ pepstatin [5]. Following brief sonication, the lysates were centrifuged at $10,000 \times \mathrm{g}$ for 10 min, and the supernatants were subjected to protein determination using BCA protein assay kit (Pierce). The samples, including those subjected to biotin switch procedure, were then resuspended in loading buffer, boiled for $5 \mathrm{~min}$, and subjected to SDS-PAGE using $40 \mu \mathrm{g}$ protein/lane. The separated proteins were transferred onto nitrocellulose membranes, blocked for $1 \mathrm{~h}$ with $5 \%$ skim milk in Tris-buffered Tween (20 mM Tris-HCl, $\mathrm{pH} 7.4$, $150 \mathrm{mM} \mathrm{NaCl}, 0.1 \%$ Tween-20), and probed with the antibody against phosphorylated protein at $4^{\circ} \mathrm{C}$ for $16 \mathrm{~h}$. After $1 \mathrm{~h}$ incubation with the horseradish peroxidaseconjugated secondary antibody, the phosphorylated proteins were revealed using an enhanced chemiluminescence. Membranes were stripped by incubation in $1 \mathrm{M}$ Tris-HCl (pH 6.8), 10\% SDS, and $10 \mathrm{mM}$ dithiotreitol for $30 \mathrm{~min}$ at $55^{\circ} \mathrm{C}$, and probed with antibody against total cNOS, iNOS or Src. Immunoblotting was performed using specific antibodies directed against iNOS, cNOS and phospho-cNOS (Ser ${ }^{1179)}$, (Calbiochem), and cSrc (monoclonal 327, Sigma) and phospho-Src (Tyr ${ }^{416)}$, (Cell Signaling).

\subsection{Data Analysis}

All experiments were carried out using duplicate sampling, and the results are expressed as means \pm SD. Analysis of variance (ANOVA) and nonparametric Kruskal-Wallis tests were used to determine significance. 


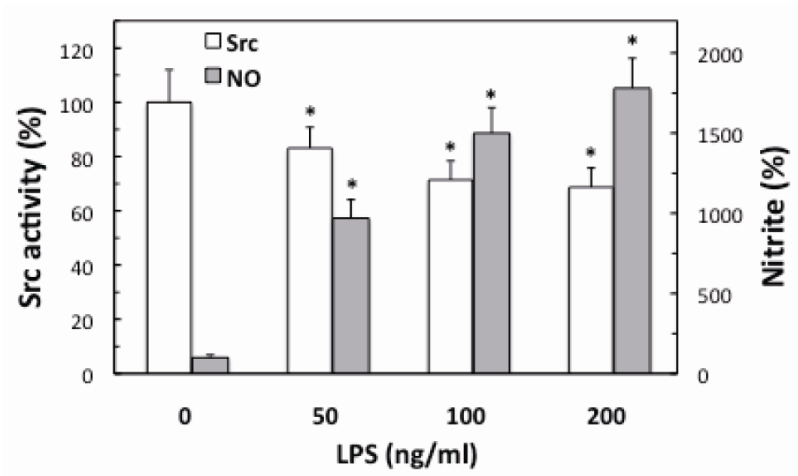

Figure 1. Effect of $P$. gingivalis LPS on the expression of Src kinase activity and nitrite production in rat sublingual salivary gland acinar cells. The acinar cells were treated with the indicated concentrations of the LPS and incubated for $16 \mathrm{~h}$. Values represent the means $\pm \mathrm{SD}$ of five experiments. ${ }^{*} p<0.05 \mathrm{com}$ pared with that of control (LPS - 0).

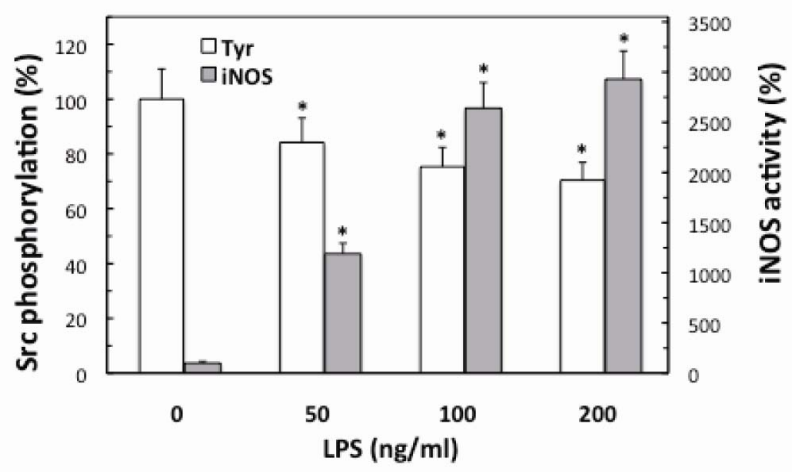

Figure 2. Effect of $P$. gingivalis LPS on Src kinase tyrosine $\left(\mathrm{Tyr}^{416}\right)$ phosphorylation and the expression of inducible nitric oxide synthase (iNOS) activity in rat sublingual salivary gland acinar cells. The cells were treated with the indicated concentrations of the LPS and incubated for $16 \mathrm{~h}$. $* p<0.05$ compared with that of control (LPS - 0).

Any difference detected was evaluated by means of post hoc Bonferroni test, and the significance level was set at $p<0.05$.

\section{RESULTS}

To examine the influence of periodontopathic bacterium, $P$. gingivalis, on the relationship between cSrc kinase activation and the disturbances in NO production, we employed rat sublingual salivary gland acinar cells exposed to $P$. gingivalis key virulence factor, LPS. We found that the LPS-induced massive increase in NO production was associated with a dose-dependent decrease in the acinar cell Src activity, which at $100 \mathrm{ng} / \mathrm{ml}$ LPS showed a $28.6 \%$ decrease (Figure 1). Moreover, the inhibitory effect of the LPS, at $100 \mathrm{ng} / \mathrm{ml}$, on cSrc activity was reflected in a $25 \%$ drop in the enzyme $\mathrm{Tyr}^{416}$ phosphorylation, and a 30\% drop in the enzyme $\mathrm{Tyr}^{416}$

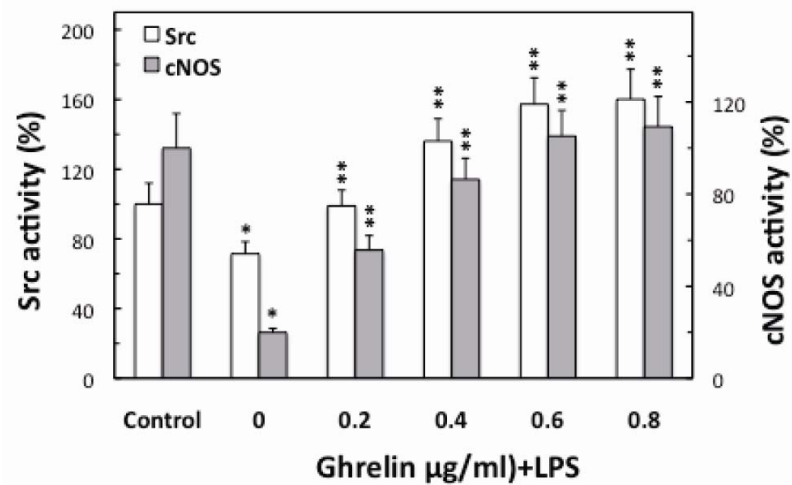

Figure 3. Effect of ghrelin on $P$. gingivalis LPS-induced changes in sublingual salivary gland acinar cell expression of Src kinase and cNOS activities. The cells, preincubated with the indicated concentrations of ghrelin, were treated with the LPS at $100 \mathrm{ng} / \mathrm{ml}$ and incubated for 16 h. ${ }^{*} p<0.05$ compared with that of control. ${ }^{* *} p<0.05$ compared with that of LPS alone.

phosphorylation occurred at $200 \mathrm{ng} / \mathrm{ml}$ LPS (Figure 2). We also established that the disturbances in NO production elicited in the acinar by $P$. gingivalis LPS at 100 $\mathrm{ng} / \mathrm{ml}$ were manifested by a 26.4-fold up-regulation in iNOS activity (Figure 2), while the activity of cNOS showed a 5.2-fold decrease (Figure 3).

Our further results revealed that preincubation of the acinar cells with ghrelin led to a concentration-dependent reversal in the LPS-induced suppression of cSrc activity and the extent of its protein phosphorylation on $\mathrm{Tyr}^{416}$. As a result the activity of cSrc in the presence of $0.6 \mu \mathrm{g} / \mathrm{ml}$ ghrelin increased 2.2-fold over that of the LPS (Figure 3), while the Src protein phosphorylation at $\mathrm{Tyr}^{416}$ showed a 2.3-fold increase (Figure 4). Further-

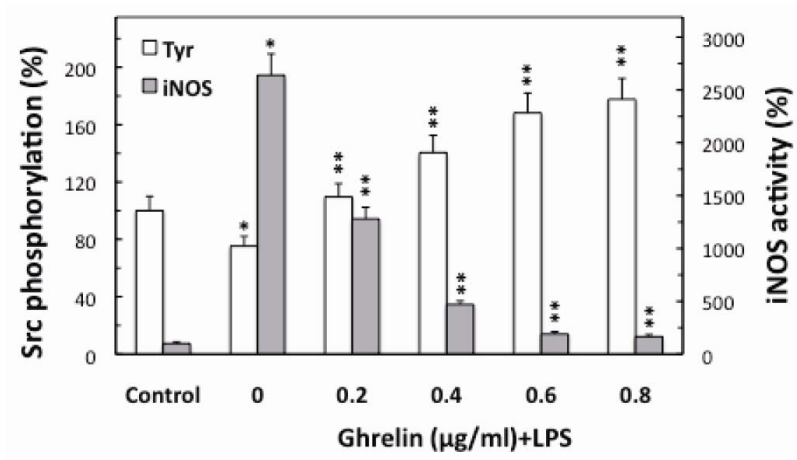

Figure 4. Effect of ghrelin on $P$. gingivalis LPS-induced changes in Src kinase tyrosine $\left(\mathrm{Tyr}^{416}\right)$ phosphorylation and the expression of iNOS activity in sublingual salivary gland acinar cells. The cells, preincubated with the indicated concentrations of ghrelin, were treated with the LPS at $100 \mathrm{ng} / \mathrm{ml}$ and incubated for $16 \mathrm{~h}$. Values represent the means $\pm \mathrm{SD}$ of five experiments. ${ }^{*} p<0.05$ compared with that of control. ${ }^{* *} p<0.05$ compared with that of LPS alone. 


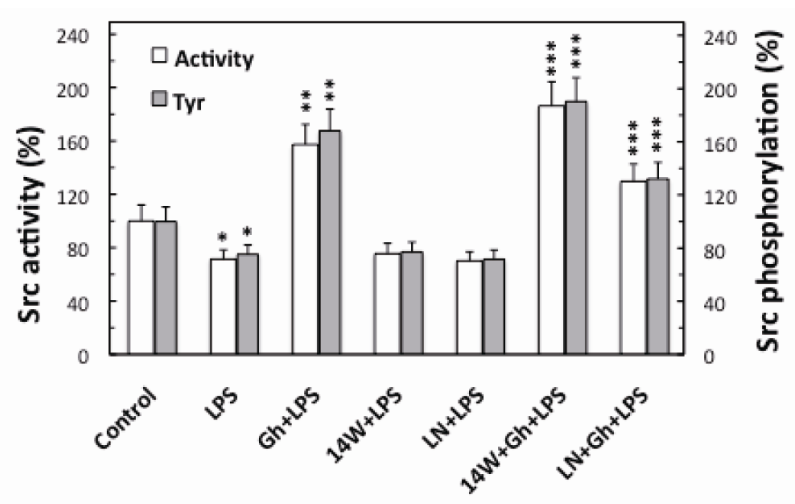

Figure 5. Effect of iNOS inhibitor, 1400W, and cNOS inhibitor, L-NAME, on the ghrelin (Gh)-induced changes in Src kinase activity and its phosphorylation at tyrosine $\left(\mathrm{Tyr}^{416}\right)$ in the salivary gland acinar cell exposed to $P$. gingivalis LPS. The cells, preincubated with $30 \mu \mathrm{M} 1400 \mathrm{~W}(14 \mathrm{~W})$, or $200 \mu \mathrm{M}$ L-NAME (LN), were treated with $\mathrm{Gh}$ at $0.6 \mu \mathrm{g} / \mathrm{ml}$ and incubated for $16 \mathrm{~h}$ in the presence of $100 \mathrm{ng} / \mathrm{ml}$ LPS. Values represent the means $\pm \mathrm{SD}$ of five experiments. ${ }^{*} p<0.05$ compared with that of control. ${ }^{* *} p<0.05$ compared with that of LPS alone. $* * * p<0.05$ compared with that of $\mathrm{Gh}+\mathrm{LPS}$.

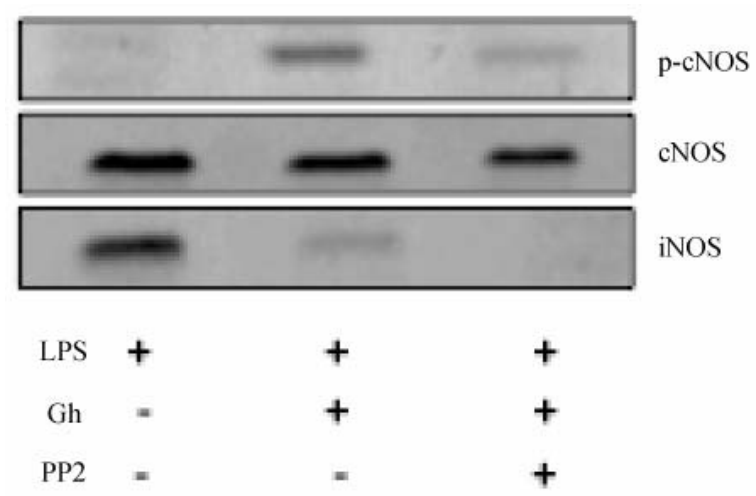

Figure 6. Effect of ghrelin (Gh) on $P$. gingivalis LPS-induced changes in the expression of iNOS protein and cNOS phosphorylation in the salivary gland acinar cells. The cells were treated with Gh at $0.6 \mu \mathrm{g} / \mathrm{ml}$ or Src inhibitor, PP2 at $20 \mu \mathrm{M}+$ $\mathrm{Gh}$, and incubated for $16 \mathrm{~h}$ in the presence of $100 \mathrm{ng} / \mathrm{ml} \mathrm{LPS}$. Cell lysates were resolved on SDS-PAGE, transferred to nitrocellulose and probed with phosphorylation specific cNOS (pcNOS) antibody, and after stripping the membranes were probed with anti-cNOS and anti-iNOS antibody. The immunoblots shown are representative of three experiments.

more, we observed that ghrelin at $0.6 \mu \mathrm{g} / \mathrm{ml}$ evoked a 5.3-fold increase in the acinar cell cNOS activity (Figure 3), and produced a 13.9-fold reduction in the LPSinduced iNOS activity (Figure 4).

To reveal further insight into the relationship between ghrelin-induced changes in the activity cNOS and iNOS enzymes and the acinar cell cSrc activation, we examined the role of NO generated by the NOS isozyme system. For this, the cells prior to incubation with ghrelin were pretreated with cNOS inhibitor, L-NAME, or iNOS inhibitor, $1400 \mathrm{~W}$, and assayed for cSrc activity as wells as the extent of its protein phosphorylation at $\mathrm{Tyr}^{416}$. The results revealed that ghrelin-induced up-regulation in cSrc activity and $\mathrm{Tyr}^{416}$ phosphorylation was subject to inhibition by cNOS inhibitor, L-NAME, whereas preincubation with iNOS inhibitor, $1400 \mathrm{~W}$, produced an amplification in the effect of ghrelin on Src activity and the extent of its protein phosphorylation at $\mathrm{Tyr}^{416}$ (Figure 5). These data, thus, indicate that ghrelin-induced Src activation through its $\mathrm{Tyr}^{416}$ phosphorylation occurs with the involvement of cNOS.

As NO generated by iNOS plays a role in $P$. gingivalis LPS-induced cNOS S-nitrosylation that interferes with the enzyme activation through phosphorylation at $\operatorname{Ser}^{1179}$ [5], we next examined the influence of ghrelin on the expression of iNOS protein and cNOS phosphorylation. The acinar cells prior to incubation with the LPS were pretreated with ghrelin or ghrelin plus Src inhibitor, PP2, and the lysates were probed with antibodies directed against iNOS, cNOS and phosphorylated cNOS $\left(\mathrm{Ser}^{1179}\right)$. As shown in Figure 6, the effect of the LPS was manifested in the induction of iNOS protein expression and the inhibition in cNOS phosphorylation, while the countering effect of ghrelin was reflected in a marked reduction in the iNOS protein expression and the increase in cNOS phosphorylation at Ser ${ }^{1179}$. Moreover, the suppression of ghrelin effect on cNOS phosphorylation as well as further reduction in iNOS protein was observed in the presence of Src kinase inhibitor, PP2 (Figure 6), thus suggesting the involvement of $\mathrm{cSrc}$ in the regulation of NOS isozyme system at both translational and posttranslational levels.

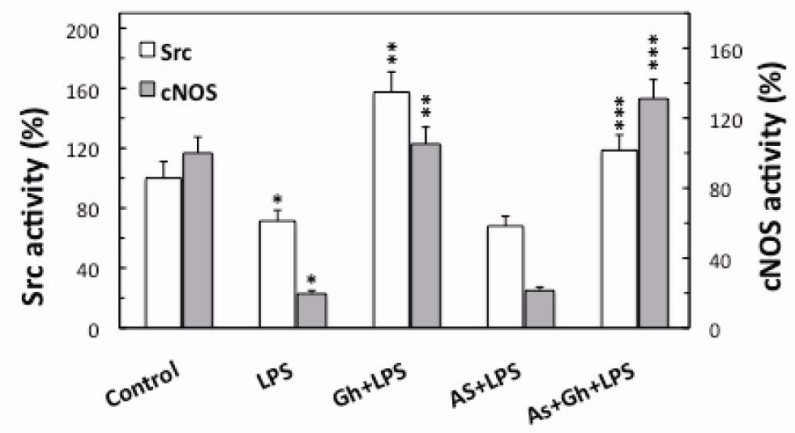

Figure 7. Effect of ascorbate on the ghrelin (Gh)-induced changes in the expression of Src kinase and cNOS activities in sublingual salivary gland acinar cells exposed to $P$. gingivalis LPS. The cells, preincubated with $300 \mu \mathrm{M}$ ascorbate (As), were treated with $\mathrm{Gh}$ at $0.6 \mu \mathrm{g} / \mathrm{ml}$ and incubated for $16 \mathrm{~h}$ in the presence of $100 \mathrm{ng} / \mathrm{ml}$ LPS. Values represent the means \pm SD of five experiments. ${ }^{*} p<0.05$ compared with that of control. ${ }^{* *} p<0.05$ compared with that of LPS alone. ${ }^{* * *} p<0.05$ compared with that of Gh + LPS. 


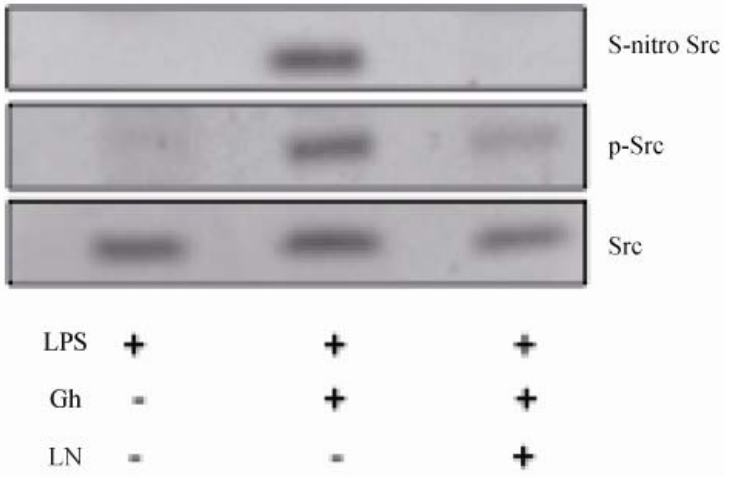

Figure 8. Effect of ghrelin (Gh) on $P$. gingivalis LPS-induced Src kinase S-nitrosylation. The salivary gland acinar cells were treated with Gh $(0.6 \mu \mathrm{g} / \mathrm{ml})$, or cNOS inhibitor, L-NAME (200 $\mu \mathrm{M})+\mathrm{Gh}$, and incubated for $16 \mathrm{~h}$ in the presence of $100 \mathrm{ng} / \mathrm{ml}$ LPS. A portion of the cell lysates was processed by biotin switch procedure for protein S-nitrosylation and, along with the reminder of the lysates, resolved on SDS-PAGE, transferred to nitrocellulose and probed with phospho-Src $\left(\mathrm{Tyr}^{416}\right)$ antibody, and after stripping reprobed with anti-Src antibody. The immunoblots shown are representative of three experiments.

Further, we found that ghrelin countering effect on the LPS-induced Src activation in the acinar cells of salivary gland displayed susceptibility to suppression by nitrosothiols reducing agent, ascorbate, which also produced enhancement in the effect of ghrelin on cNOS activity (Figure 7). Hence, to ascertain the relationship between Src kinase S-nitrosylation and its activation through phosphorylation, we examined the dependence of cSrc S-nitrosylation on the ghrelin-induced cNOS activation by the biotin switch method $[23,24]$. The acinar cells were incubated with $P$. gingivalis LPS or ghrelin + LPS or cNOS inhibitor, L-NAME, + ghrelin + LPS, and the lysates following the biotin switch procedure were probed with antibodies directed against phospho-cSrc $\left(\mathrm{Tyr}^{416)}\right.$ and total Src. Western blot analysis revealed that ghrelin countering effect on the LPS-induced suppression in cSrc activity was manifested by a marked increase in both the Src kinase S-nitrosylation as well as its protein phosphorylation. Moreover, the blockage of cNOS activity with L-NAME, not only caused the loss in cSrc S-nitrosylation but was also accompanied by a substantial decrease in Src protein phosphorylation at $\mathrm{Tyr}^{416}$ (Figure 8). Thus, ghrelin countering effects on $P$. gingivalis-induced inflammatory changes are manifested in the enhancement in Src activation through cNOSdependent S-nitrosylation and the increase in its phosphorylation.

\section{DISCUSSION}

$P$. gingivalis is a Gram-negative bacterium found in periodontal packets of patients with periodontitis, a chronic inflammatory disease that affects $10 \%-15 \%$ of adult population and is a major cause of adult tooth loss [25, 26]. The oral mucosal responses to $P$. gingivalis and its key virulence factor, cell wall LPS, are characterized by a massive rise in epithelial cell apoptosis and proinflammatory cytokine production, and the disturbances in NOS isozyme system responsible for NO generation [4$6,19,27]$. Investigations into the endogenous factors capable of influencing the extent of mucosal inflammatory responses along the alimentary tract, including that of oral cavity, have brought to focus the importance of a peptide hormone, ghrelin [1-4,28]. A growing body of evidence, furthermore, points to ghrelin as a principal modulator of the mucosal NOS [4-6,17]. The mechanism that underlies the regulation of NO signaling by ghrelin relies on the receptor (GHS-R1a)-mediated activation of $\mathrm{G}$ protein-dependent network of protein kinases, including that of membrane-associated non-receptor tyrosine kinase, cSrc [7-10].

As Src kinase plays a pivotal role in the transduction of signals that regulate the activity of NOS isozyme system $[8,13,14]$, in this study we investigated the influence of $P$. gingivalis LPS on the processes associated with Src activation. Our findings revealed that the LPS-induced drop in sublingual salivary gland acinar cells activity of cNOS and up-regulation in iNOS was associated with the suppression in the activity of cSrc. Moreover, the suppression in cSrc activity was reflected in a decrease in the kinase phosphorylation at $\mathrm{Tyr}^{416}$. Furthermore, preincubation of the acinar cells with ghrelin exerted countering effect on the LPS-induced impairment in cSrc activity and the extent of its phosphorylation on $\mathrm{Tyr}^{416}$, and was accompanied by an increase in the cNOS activity and a marked reduction in the activity of iNOS. These findings are thus in keeping with the literature data suggesting the involvement of cSrc kinase in the regulation of NOS isozyme system at both transcriptional and post-transcriptional levels $[13,14]$.

Indeed, in concordance with the documented involvement of cSrc in post-translational cNOS activation through phosphorylation $[5,18,29]$, we found that the induced up-regulation in cNOS activity by ghrelin was reflected in the increase of enzyme protein phosphorylation at Ser $^{1179}$. Also, as up-regulation in iNOS activity in response to LPS involves transcriptional factor NF- $\mathrm{KB}$ transactivation of iNOS gene for the induction in the enzyme protein [30-32], we analyzed the influence of ghrelin on the acinar cell iNOS protein expression. We found that $P$. gingivalis LPS induction in iNOS activity was associated with the increase in the enzyme protein expression, while the countering effect of ghrelin, was reflected in a marked inhibition of the iNOS protein expression that was further suppressed in the presence of 
Src kinase inhibitor, PP2.

Next we addressed the relationship between the ghrelin-induced changes in activity of cNOS and iNOS enzymes, and the Src kinase activation. As up-regulation in cSrc activation through autophosphorylation on $\mathrm{Tyr}^{416}$ has been reported in the presence of the exogenous NO donors as well as the NO produced by endothelial NOS [13-15], we examined the effect of NOS inhibitors on cSrc activity and the extent of its protein phosphorylation at $\mathrm{Tyr}^{416}$. We found that ghrelin-induced up-regulation in the acinar cell cSrc activity and $\mathrm{Tyr}^{416}$ phosphorylation displayed susceptibility to cNOS inhibitor, L-NAME, while an amplification in the ghrelin effect on cSrc activation was attained with the inhibitor of iNOS, 1400 W. From this, we concluded that cNOS plays an essential role in ghrelin-induced activation of cSrc in the acinar cells. Furthermore, the countering effect of ghrelin on the LPS-induced changes in cSrc activation was susceptible to the suppression by nitrosothiols reducing agent, ascorbate, which also produced an enhancement in the effect of ghrelin on cNOS activity. These data, together with the known susceptibility of S-nitrosylated proteins to reduction by ascorbic acid [4,5,14,15,23,24], demonstrate that $P$. gingivalis LPS-induced disturbances in the acinar cell cNOS and cSrc protein S-nitrosylation patterns interfere with the activation of both cNOS and cSrc. Moreover, our results suggest that ghrelin-induced up-regulation in cSrc activity through phosphorylation at $\mathrm{Tyr}^{416}$ is intimately linked to the events of the kinase protein S-nitrosylation by NO generated by the cNOS.

Our assertion is further supported by the literature evidence indicating that ascorbate treatment both increases cNOS activity and reduces the enzyme protein Snitrosylation, and that the countering effect of ghrelin on the LPS-induced impairment in cNOS activity is associated with the loss of the enzyme protein S-nitrosylation and the increase in its phosphorylation at $\operatorname{Ser}^{1179}[5,13$, 32]. Indeed, the accumulating evidence demonstrates that protein modification through targeted S-nitrosylation at the critical cysteine, with the participation of both constitutive and inducible forms of NOS system, is a post-translational event of significance to the regulation of signal transduction pathways by NO [4-6,13-15,17,32, 33]. Moreover, NO-induced Src S-nitrosylation at the critical cysteine residues located within the C-terminal region of its catalytic domain has been reported to promote cSrc activation through autophosphorylation at $\mathrm{Tyr}^{416}$ [13-15].

Hence, to assess the role of ghrelin in countering $P$. gingivalis LPS-induced interference with cSrc activation in the acinar cells, we examined the dependence of Src S-nitrosylation on the ghrelin-induced cNOS activation by the biotin switch assay. Western blot analysis of the acinar cell lysates revealed that ghrelin countering effect on the LPS-induced suppression in cSrc activity was manifested by a marked increase in the kinase protein Snitrosylation as well as phosphorylation at $\mathrm{Tyr}^{416}$. Furthermore, the suppression of ghrelin effect on NO production with cNOS inhibitor, L-NAME, caused the loss in cSrc S-nitrosylation and a decrease in the kinase phosphorylation. These findings thus imply that the changes evoked by $P$. gingivalis in the activity of NOS isozyme system involved in NO generation are of direct relevance to cSrc kinase activation through autophosphorylation at $\mathrm{Tyr}^{416}$, and point to the role of $\mathrm{cSrc}^{\mathrm{S}}$ S-nitrosylation in the protective mechanism of ghrelin action.

In conclusion, our findings demonstrate that $P$. gingivalis-induced up-regulation in the acinar cell iNOS leads to disturbances in cNOS phosphorylation that exerts the detrimental effect on the processes of cSrc kinase activation through cNOS mediated S-nitrosylation. We also show that the effects of ghrelin on $P$. gingivalis-induced inflammatory disturbances are manifested in the enhancement in Src activation through Snitrosylation and the increase in its phosphorylation at Tyr $^{416}$.

\section{REFERENCES}

[1] Kojima, M., Hosoda, H., Date, Y., Nakazato, M. and Kangawa, K. (1999) Ghrelin is a growth-hormone-releasing acylated peptide from stomach. Nature, 402, 656660. doi:10.1038/45230

[2] Kojima, M. and Kangawa, K. (2005) Ghrelin: Structure and function. Physiology Reviews, 85, 495-522. doi:10.1152/physrev.00012.2004

[3] Groschl, M., Topf, H.G., Bohlender, J., Zenk, J., Klussmann, S., Dotsch, J., Rascher, W. and Rauh, M. (2005) Identification of ghrelin in human saliva: Production by the Salivary glands and potential role in proliferation of oral keratinocytes. Clinical Chemistry, 51, 997-1006. doi:10.1373/clinchem.2004.040667

[4] Slomiany, B.L. and Slomiany, A. (2010) Constitutive nitric oxide synthase-mediated caspase-3 S-nitrosylation in ghrelin protection against Porphyromonas gingivalisinduced salivary gland acinar cell apoptosis. Inflammopharmacology, 18, 119-125. doi:10.1007/s10787-010-0035-7

[5] Slomiany, B.L. and Slomiany, A. (2010) Suppression by ghrelin of Porphyromonas gingivalis-induced constitutive nitric oxide synthase S-nitrosylation and apoptosis in Salivary gland acinar cells. Journal of Signal Transduction, 2010, Article ID 280464. doi:10.1155/2010/643642

[6] Slomiany, B.L. and Slomiany, A. (2010) Role of ghrelin in modulation of S-nitrosylation-dependent Akt inactivation induced in salivary gland acinar cells by Porphyromonas gingivalis. Health, 2, 1448-1455. doi:10.4236/health.2010.212215

[7] Pierce, K.L., Premont, R.T. and Lefkowitz, R.J. (2002) 
Seven-transmembrane receptors. Nature Reviews Molecular Cell Biology, 3, 639-650.

doi:10.1038/nrm908

[8] Lodeiro, P., Theodoropoulou, M., Pardo, M., Casanueva, F.F. and Camina, J.P. (2009) c-Src regulates Akt signaling in response to ghrelin via b-arrestin signalingindependent and-dependent mechanism. PLoS ONE, $\mathbf{4}$ Article ID e4686.

[9] Roskoski, R. (2004) Src protein-tyrosine kinase structure and regulation. Biochemical and Biophysical Research Communications, 324, 1155-1164. doi:10.1016/j.bbrc.2004.09.171

[10] Lutrell, D.K. and Lutrell, L.M. (2004) Not so strange bedfellows: G-protein-coupled receptors and Src family kinases. Oncogene, 23, 7969-7978. doi:10.1038/sj.onc.1208162

[11] Chiaguri, P. (2008) Src redox regulation: There is more than meets the eye. Molecules and Cells, 26, 329-337.

[12] Cayer, M.P., Proulx, M., Ma, X.Z., Sakac, D., Giguere, J.F., Drouin, M., Neron, S., Branch, D.R. and Jung, D. (2009) c-Src tyrosine co-associates with and phosphorylates signal transducer and activator of transcription $5 \mathrm{~b}$ which mediates the proliferation of normal human B lymphocytes. Clinical \& Experimental Immunology, 156, 419-427. doi:10.1111/j.1365-2249.2009.03917.x

[13] Hess, D.T., Matsumoto, A., Kim, S.O., Marshall, H.E. and Stamler, J.S. (2005) Protein S-nitrosylation: Purview and parametrs. Nature Reviews Molecular Cell Biology, 6, 150-166. doi:10.1038/nrm1569

[14] Rahman, M.A., Senga, T., Ito, S., Hyodo, T., Hasegawa, H. and Hamaguchi, M. (2010) S-nitrosylation at cysteine 498 of c-Src tyrosine kinase regulates nitric oxidemediated cell invasion. Journal of Biological Chemistry, 285, 3806-3814. doi:10.1074/jbc.M109.059782

[15] Akhand, A.A., Pu, M., Senga, T., Kato, M., Suzuki, H., Miyata, T., Hamaguchi, M. and Nakashima, I. (1999) Nitric oxide controls Src kinase activity through a sufhydryl group modification-mediated Tyr-527-independent and Tyr-416-linked mechanism. Journal of Biological Chemistry, 274, 25821-25826. doi:10.1074/jbc.274.36.25821

[16] Minetti, M., Mallozzi, C. and Stassi, A.M. Di (2002) Peroxynitrite activates kinases of the Src family and upregulates tyrosine phosphorylation signaling. Free Radical Biology \& Medicine, 33, 744-754. doi:10.1016/S0891-5849(02)00891-2

[17] Xu, X., Jhun, B.S., Ha, C.H. and Jin, Z.G. (2008) Molecular mechanisms of ghrelin-mediated endothelial nitric-oxide synthase activation. Endocrinology, 149, 41834192. doi:10.1210/en.2008-0255

[18] Slomiany, B.L. and Slomiany, A. (2003) Activation of peroxisome proliferator-activated receptor $\mathrm{g}$ impedes Porphyromonas gingivalis lipopolysaccharide interference with salivary mucin synthesis through phosphatidy-linositol 3-kinase/ERK pathway. (2003) Journal of Physiology and Pharmacology, 54, 3-15.

[19] Slomiany, B.L. and Slomiany, A. (2005) Role of leptin in modulation of Porphyromonas gingivalis lipopolysaccharide-induced up-regulation of endothelin-1 in salivary gland acinar cells. IUBMB Life, 57, 591-595. doi:10.1080/15216540500215598

[20] Green, L.C., Wagner, D.A., Glogowski, J., Skipper, P.L.,
Wishnok, J.S. and Tannenbaum, S.R. (1982) Analysis of nitrte, nitrite, and [15N] nitrate in biological fluids. Analytical Biochemistry, 126, 131-138. doi:10.1016/0003-2697(82)90118-X

[21] Lee, S., Lin, X., Nam, N.H., Parang, K. and Sun, G. (2003) Determination of the substrate-docking site of protein tyrosine kinase c-terminal Src kinase. Proceedings of the National Academy of Sciences of the United States of America, 100, 14707-14712. doi:10.1073/pnas.2534493100

[22] Tamiya, S. and Delamere, N.A. (2005) Studies of tyrosine phosphorylation and Src family tyrosine kinases in the lens epithelium. Investigative Ophthalmology \& Visual Science, 46, 2076-2081. doi:10.1167/iovs.04-1199

[23] Jaffrey, S.R., Erdjument-Bromage, H., Ferris, D., Tempst, P. and Snyder, S.H. (2001) Protein S-nitrosylation: A physiological signal for neuronal nitric acid. Nature Cell Biology, 3, 193-197. doi:10.1038/35055104

[24] Forrester, M.T., Foster, M.W. and Stamler, J.S. (2007) Assessment and application of the biotin switch technique for examining protein S-nitrosylation under conditions of pharmacologically induced oxidative stress. Journal of Biological Chemistry, 282, 13977-13983. doi:10.1074/jbc.M609684200

[25] Ximenz-Fyvie, L.A., Haffajee, A.D. and Socransky, S. (2000) Micorbial composition of supra- and subgingival plaque in subjects with adult periodontitis. Journal of Clinical Periodontology, 27, 722-732. doi:10.1034/j.1600-051x.2000.027010722.x

[26] Nonnenmacher, C., Mutters, R. and de Jacoby, L.F. (2001) Microbiological characteristics of subgingival microbiota in adult periodontitis, localized juvenile periodontitis and rapidly progressive periodontitis subjects. Clinical Microbiology and Infection, 7, 213-221. doi:10.1046/j.1469-0691.2001.00210.x

[27] Wang, P.L. and Ohura, K. (2002) Porphyromonas gingivalis lipopolysaccharide signaling in gingival fibroblasts-CD14 and Toll-like receptors. Critical Reviews in Oral Biology and Medicine, 13, 132-142. doi:10.1177/154411130201300204

[28] Waseem, T., Duxbury, M., Ito, H., Ashley, S.W. and Robinson, M.K. (2008) Exogenous ghrelin modulates release of proinflammatory and anti-inflammatory cytokines in LPS-stimulated macrophages through distinct signaling pathways. Surgery, 143, 334-342. doi:10.1016/j.surg.2007.09.039

[29] Haynes, M.P., Li, L., Sinha, D., Russell, K.S., Hisamoto, K., Baron, R., Collinge, M., Sessa, W.C. and Bender, J.R. (2003) Src kinase mediates phosphatidylinositol3-kinase /Akt-dependent rapid endothelial nitric-oxide synthase activation by estrogen. Journal of Biological Chemistry, 278, 2118-2123. doi:10.1074/jbc.M210828200

[30] Korhonen, R., Lahti, A., Kankaanranta, H. and Moilanen, E. (2005) Nitric oxide production and signaling in inflammation. Current Drug Targets: Inflammation \& Allergy, 4, 471-479. doi:10.2174/1568010054526359

[31] Yu, S.M., Wu, J.F., Lin, T.L. and Kuo, S.C. (328) Inhibition of nitric oxide synthase expression by PPM-18, a novel anit-inflammatory agent, in vitro and in vivo. 
Biochemical Journal, 328, 363-369.

[32] Slomiany, B.L. and Slomiany, A. (2011) Ghrelin suppression of Helicobacter pylori induced S-nitrosylationdependent gastric mucosal Akt inactivation exerts modulatory influence on gastric mucin synthesis. Inflammopharmacology,19, 89-97. doi:10.1007/s10787-011-0078-4

[33] Erwin, P.A., Lin, A.J., Golan, E. and Michel, T. (2005) Receptor-regulated dynamic S-nitrosylation of endothelial nitric-oxide synthase in vascular endothelial cells. Journal of Biological Chemistry, 280, 19888-19894.

doi:10.1074/jbc.M413058200 